\title{
Finite State Machine Model in Jungle Adventure Game an Introduction to Survival Skills
}

\author{
Reza Andrea \\ Software Engineering Technology, Agricultural Polytechnic of Samarinda, 75131, Indonesia \\ Email: reza@wicida.ac.id
}

Sefty Wijayanti and Nursobah

STMIK Widya Cipta Dharma, Samarinda, 75123, Indonesia

Email: seftywicid@gmail.com,nursobah@wicida.ac.id

Received: 17 April 2021; Accepted: 01 June 2021; Published: 08 August 2021

\begin{abstract}
Game is one of the big industries today and can be an alternative entertainment and fun for children and adults. Game can be used as an interactive and interesting learning media. One of the platform game development methods is the Finite State Machine (FSM). This method is used to adjust the behavior of the NPC (Non-Player Character) to guide the player through the game. This study developed an Android-based "Jungle Adventure" game with interesting gameplay to make the learning process very enjoyable so that the player is expected to be able to play while learning. Combination NPC with FSM will make that responses under certain conditions, and NPC will accompany player like a friend survival.
\end{abstract}

Index Terms: Game, Adventure, Jungle, Non Playing Character, Finite State Machine

\section{Introduction}

The "Jungle Adventure" game is an Android Role Playing Game, where the player is required to avoid all NPCs in the form of attacking ghosts to enter a safe place so they can go to the NPC in front of the gate to answer questions and head to the next stage.

The game has two definitions. First, game for fun without seeking to win or lose. Second, game for fun and satisfaction but still looking to win [1]. Games can be classified into two major parts namely physical games and electronic games. Electronic games are currently growing very rapidly with a variety of new consoles [2].

Unity $3 \mathrm{D}$ is a cross-platform-based game engine. Unity can be used to make a game on a computer, smartphone, android, iPhone, PS3, even X-BOX device. Unity is an integrated tool for game development, building architecture, and simulation. Unity can be used for PC games and online games. Online games require a plugin, namely Unity Web Player or the same as Flash Player in the browser [3,4,5].

This study developed an educational game entitled "Jungle Adventure" with the Finite State Machine (FSM) method. FSM is one of the best-known methods for modeling the behavior of an agent or NPC in a game. This is due to the simplicity and ease of FSM implementation [6]. The multimedia development methodology consists of 6 stages, namely concept, design, material collecting, assembly, testing, and distribution [7]. Combination NPC with FSM will make that responses under certain conditions, and NPC will accompany player like a friend survival. The players can get insight through in-game quizzes. This application will displays simple education about survival skills in the form of quizzes. This game developed by adding survival skill education.

\section{Literature Review}

Studies on games with the same technique have been carried out, namely, "The Development of 3D Survival Simulation Game for Identifying Safe Food and Water in Borneo Forest", the game was developed using Unity Engine by applying 3-dimensional graphics to walk around Borneo Forest. this research was aimed to develop a survival simulation game that teach the player how to identify safe food and water in Borneo forest. The game was developed in six steps based on Luther's steps of authoring multimedia. At the end of the development process, the feasibility of the game as learning media is tested using pre-test and post-test method. Statistical analysis using paired t-test showed that the post-test result $(\mathrm{M}=77.33, \mathrm{SD}=5.37)$ was significantly higher than the pre-test result $(\mathrm{M}=56.67, \mathrm{SD}=8.24))$; $\mathrm{t}(29)=18.49, \mathrm{p}<0.001$. This indicates that the game is feasible in teaching the knowledge to the player. In the future, 
this game can be an alternative and practical solution for teaching survival skill. [11]. There are two types of FSM, namely FSM with output and FSM without output. FSM without output is used to identify whether the input is known or not. For example, the compiler program to check whether the command used by the user is true or false [12] basically, the implementation of FSM can be divided into three ways, where each method has its own advantages and disadvantages. The three methods are the Traditional Way, Lookup Table, and Object-Oriented [13,14] as shown in Fig. 1 .

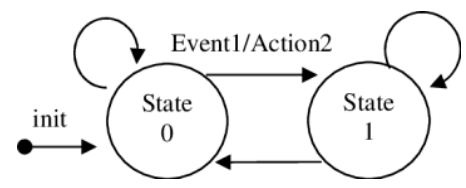

Fig.1. State Transition Diagram

Finite state machine is not a new method. FSM has been around for a long time where the concept of decomposition has usually been understood and is often used by experts in developing computer programs. There are several abstract modeling techniques for the definition and design of FSM. The State Transition Diagram or known as a Bubble Diagram shows the relation between the states and the input causing the state transition. The State-Action Decision Making Diagram is a simple flow chart with the addition of a bubble showing the waiting for input. State graph diagram with UML notation showing the individual properties of objects as state numbers and the transitions of those states. Command Hierarchy Analysis is a command decomposition technique to divide orders into suborders according to the sequence of events [15].

\section{Methodology}

"Jungle Adventure" is an Android game to introduce survival equipped with simple quizzes. This game is designed for 13+ users. This study was conducted in several stages of multimedia development, namely:

1. Conduct a concept on the educational game development process and the algorithm used, as well as collect the game development materials.

2. The game development process with the multimedia development method, starting from the design to the assembly stage of the FSM into the game system

3. Conduct beta testing in the form of a questionnaire to several people and review of these documents.

4. Analyze the results of the questionnaire and review of the application of the Finite State Machine in the game.

5. Re-distribute and re-analyze until the test results produce a satisfying percentage.

This game has four stages or arenas with different levels of difficulty and mileage. Each stage has a different question. Every time the player answers the question, the player will get a score. On the stage, the player will be chased by ghost NPCs. After the player has successfully passed the four stages, the player is declared the winner. If in the middle of the stage the player runs out of blood, the player loses and has to repeat. The FSM logic model of the Jungle Adventure game can be seen in Fig. 2, 3, 4, and Tables 1, 2, 3.

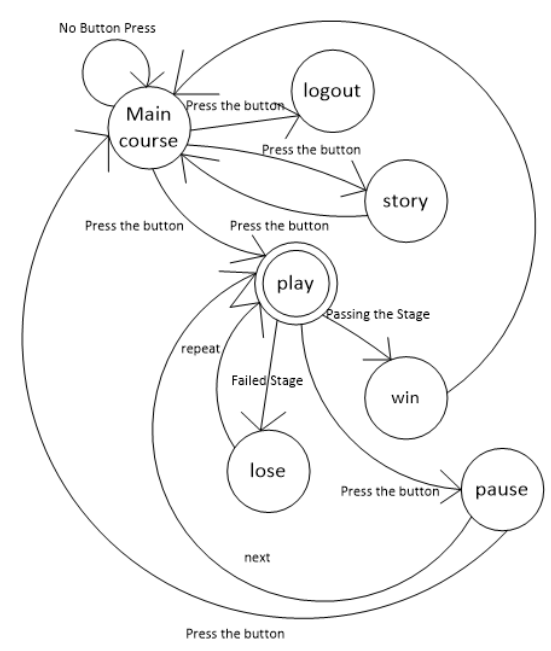


Table 1. Description of FSM model in The Fig. 2

\begin{tabular}{llll}
\hline Initial State & Event & Action & Goal State \\
\hline Main Menu & Player enters main menu & Player Presses Any Button & Exit \\
Main Menu & Player enters main menu & Player Presses Any Button & Story \\
Main Menu & Player enters main menu & Player Presses Any Button & Play \\
Story & Player plays the story & Player Presses Any Button & Main Menu \\
Initial State & Event & Action & Goal State \\
Play & Player fails & Pop-Up Notification & Lose \\
Lose & Player restarts & Player lives in early stage & Play \\
Play & Player pauses & Player Presses Any Button & Pause \\
Play & Player succeeds & Pop-Up Notification & Win \\
Win & Pop-Up Notification & Player Presses Any Button & Main Menu \\
Pause & Player resumes & Player Presses Any Button & Play \\
Pause & Player exits & Player Presses Any Button & Main Menu \\
\hline
\end{tabular}

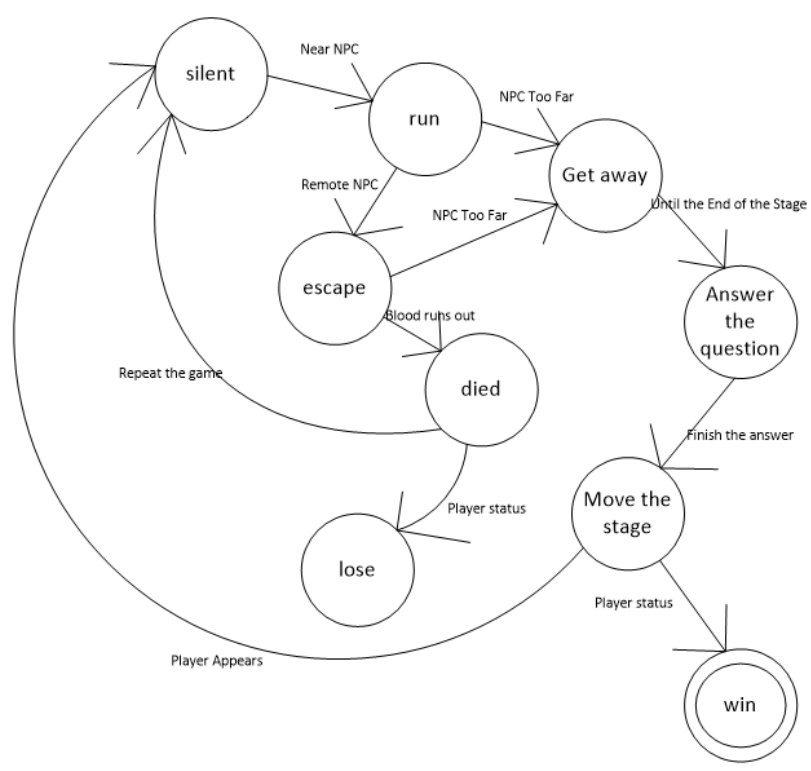

Fig.3. State transition on player controller

Table 2. Description of FSM model in The Fig. 3

\begin{tabular}{llll}
\hline $\begin{array}{l}\text { Initial } \\
\text { State }\end{array}$ & Event & Action & Goal State \\
\hline Idle & Player moves the joystick forward (Full) & Player runs & Run \\
Idle & Player moves the joystick forward (Slight) & Player walks & Walk \\
Idle & Player presses jump button & Player jumps in place & Jump \\
Idle & Player presses answer button & Player answers & Answer The Quiz \\
Run & Player moves the joystick forward (Full) & Player hits the wall & Running In Place \\
Run & Player moves the joystick forward (Slight) & Player walks & Walk \\
Walk & Player moves the joystick forward (Full) & Player runs & Run \\
Walk & Player moves the joystick forward (Slight) & Player hits the wall & Walking In Place \\
Run & Player moves the joystick forward (Full) and presses & Player does a long jump and avoids the traps & Jump \\
& jump button & & Jump \\
Walk & $\begin{array}{l}\text { Player moves the joystick forward (Slight) and presses } \\
\end{array}$ & Player does a short jump and gets trapped & \\
\hline
\end{tabular}

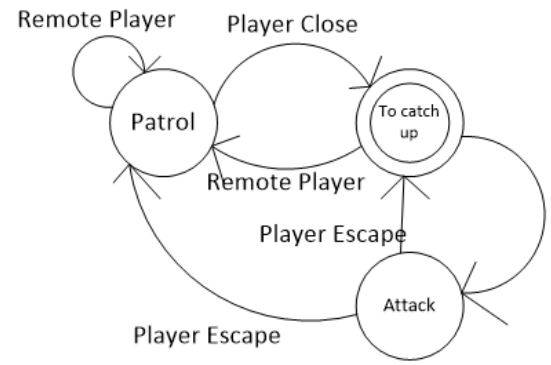

Fig.4. NPC state diagram 
Table 3. Description of FSM model in The Fig. 4

\begin{tabular}{llll}
\hline Initial State & Event & Action & Goal State \\
\hline Patrol & Player is far from NPC & NPCs continue to patrol until the next & Chase \\
& & event & \\
Chase & Player is near the NPC & NPCs chase the player & Attack \\
Attack & Player is too close to the NPC & NPCs bleed the player & Patrol \\
Patrol & Player manages to get away from NPC & NPCs patrol & Patrol \\
Attack & Player escapes the NPC & NPCs chases the player & Chase \\
\hline
\end{tabular}

\section{Result and Discussion}

The "Jungle Adventure" game is an Android Role Playing Game, where the player is required to avoid all NPCs in the form of attacking ghosts to enter a safe place so they can go to the NPC in front of the gate to answer questions and head to the next stage. This game was developed using the Finite State Machine (FSM) method.

On the main menu, there are the start, story, and exit buttons. The start button is used for the player to start the game and enter the main scene as shown in Fig. 5.

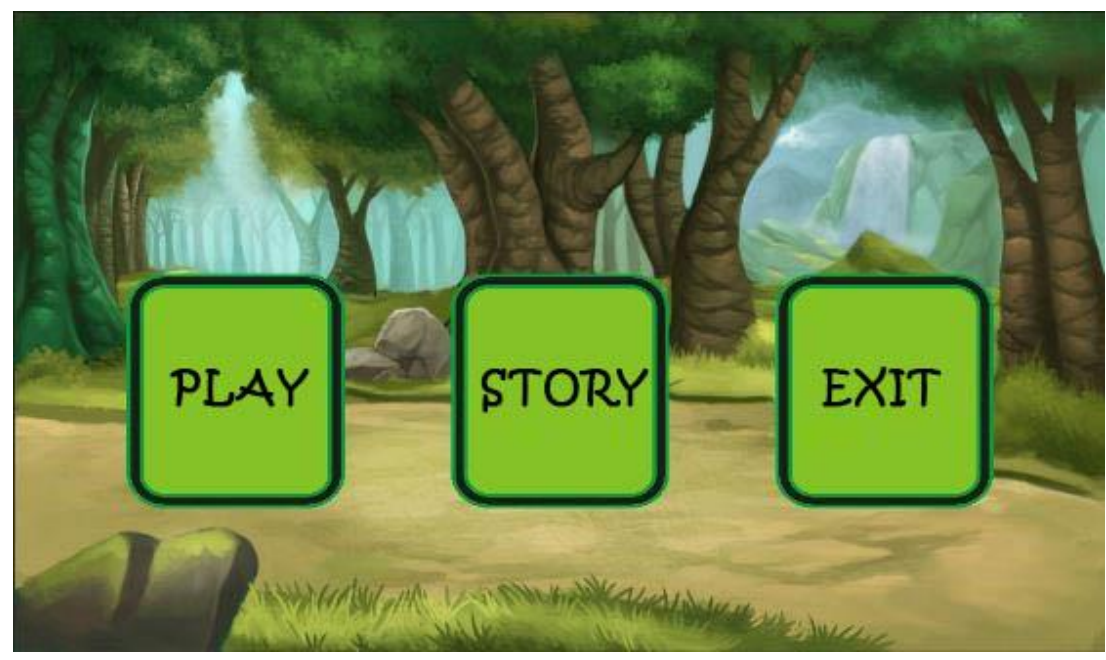

Fig. 5. Menu Scene

On stage 1, there is a joystick button to control the movement, a pause button to stop the game, a jump button to jump over traps, and a health bar. In addition, there are also 10 3D NPCs as shown in Fig. 6.

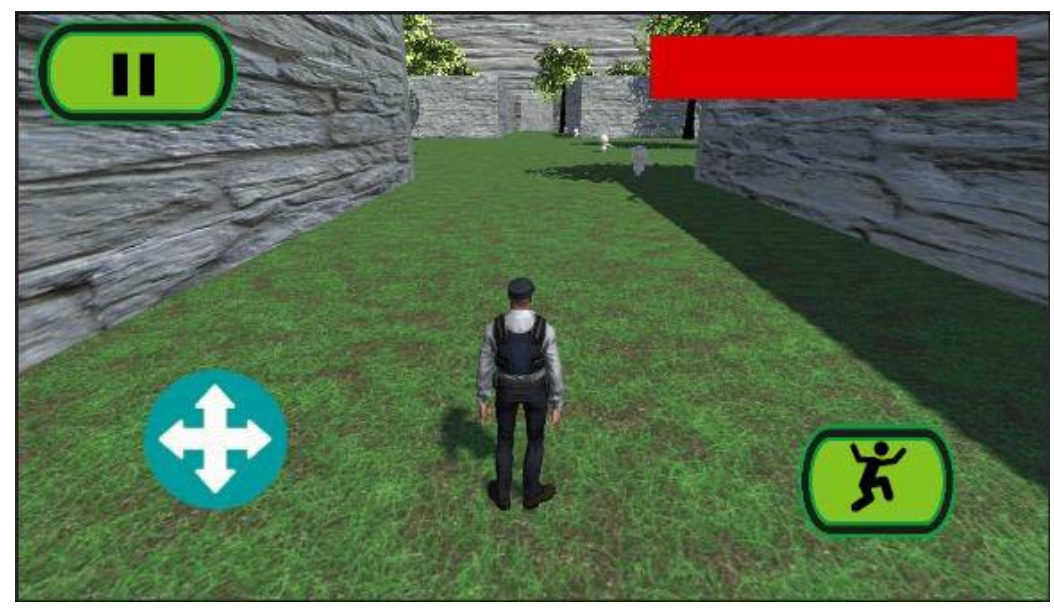

Fig.6. Game-play

In the quiz, there are questions, scores, and buttons to select answers as shown in Fig. 7. 


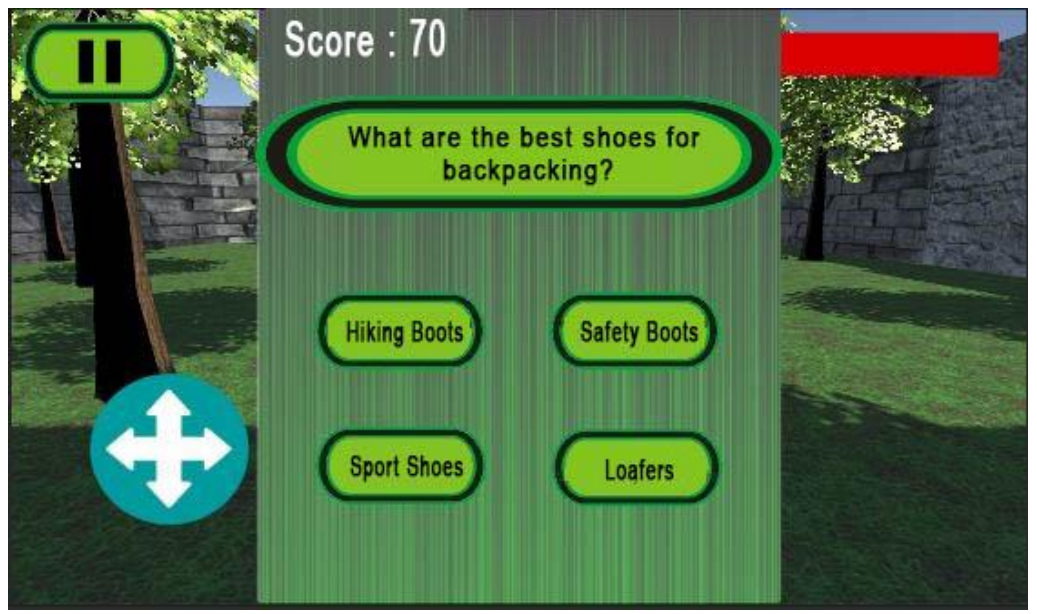

Fig.7. Question Scene

Beta Testing is carried out by one or more end-users in the actual environment. Unlike alpha testing, beta testing is performed in an uncontrollable environment. Subscribers recorded all issues (real or imaginary) during beta testing in the form of design, sound, images and were reported to the developer at regular intervals. The Finite State Machine was tested to see if the enemy moves according to the conditions described in the Finite State Machine. The results of the beta testing can be seen in Table 4 and (1).

Table 4.

\begin{tabular}{lccccr}
\hline Aspect & \multicolumn{5}{c}{ Rating } \\
\cline { 2 - 6 } & $\mathbf{- 1}$ & $\mathbf{0}$ & $\mathbf{1}$ & $\mathbf{2}$ & $\mathbf{3}$ \\
\hline Game Title & 0 & 0 & 1 & 5 & 4 \\
Game storyline & 0 & 0 & 4 & 3 & 3 \\
Responsive with the device & 0 & 0 & 3 & 4 & 3 \\
Level challenge & 0 & 0 & 3 & 4 & 3 \\
Character Design & 0 & 0 & 1 & 0 & 9 \\
Function of Button & 0 & 0 & 4 & 4 & 2 \\
Joystick Controller & 0 & 0 & 4 & 6 & 0 \\
Arena Design & 0 & 0 & 0 & 2 & 8 \\
Concept Art & 0 & 0 & 5 & 3 & 2 \\
Music Ni Game & 1 & 0 & 4 & 0 & 5 \\
\hline \hline Total & 1 & 0 & 29 & 31 & 39 \\
\hline Percentage & $1 \%$ & $0 \%$ & $29 \%$ & $31 \%$ & $39 \%$ \\
\end{tabular}

Very Poor $(-1): 1 \mathrm{x}-1=-1$

Poor $(0): 0 \times 0=0$

Average $(+1): 29 \times 1=29$

Good $(+2): 31 \times 2=62$

Very Good $(+3): 39 \times 3=117$

$$
\mathrm{Y}=\frac{\mathrm{x}}{\mathrm{n}} 100 \%
$$

$$
\mathrm{Y}=(-1+0+29+62+117) / 300=0,69
$$

From (1) shows, This game had an average beta-testing score of 69\%. 39\% end-users stated very good, 31\% good, $29 \%$ average, $0 \%$ poor, and $1 \%$ very poor. Presenting NPC as a survival guide and it can give all information about survival skill. FSM is applied to the NPC, make an autonomous character can interact reason of actions and reactions of the players. This makes the game more interactive.

\section{Conclusion}

The development of the Jungle Adventure game was through 6 stages namely concept, design, material collecting, assembly, testing, and distribution. The Finite State Machine in the Jungle Adventure game functions for NPC 
responses under certain conditions. The players can get insight through in-game quizzes. This application is only limited to the usual Survival Game which can be developed by adding missions or even better arena designs. This application only displays simple education in the form of quizzes. This game can be developed by adding other types of education. In this game, there are only 4 questions so it is possible to develop it by adding a few more questions to each stage with a timer. This game had an average beta-testing score of $69 \% .39 \%$ end-users stated very good, $31 \%$ good, $29 \%$ moderate, $0 \%$ bad, and $1 \%$ very bad. Presenting NPC as a survial guide and it can give all information about survival skill in The jungle. FSM is applied to the NPC, make an autonomous character can interact reason of actions and reactions of the players. This makes the game more interactive. For further application development, it is expected that survival skill can be added to the river or cave, and in other dangerous place in the jungle. We suggest for future work, this game can use another method is like moore machine, neural network, or combination probability with finite state machine to make the NPC more interactive

\section{Acknowledgment}

This research is funded by Directorate General of Strengthening for Ministry of Research and TechnologyNational Research and Innovation Agency of the Republic of Indonesia according the Research Contract in Fiscal Year of 2021

\section{References}

[1] J.-Y. Jung, "Application and Need of Korean Popular songs as the Educational Contents," The Journal of the Korea Contents Association, vol. 12, no. 4, pp. 174-185, 2012.

[2] A. Rachmatullah and M. Ha, "Indonesian and Korean high school student's disparities in science learning orientations: an approach to multi-group structural equation modeling," Asia-Pacific Science Education, vol. 5, no. 1, pp. 1-17, 2019.

[3] B. S. Chung and M. S. Chung, "Homepage to distribute the anatomy learning contents including Visible Korean products, comics, and books," Anatomy \& Cell Biology, vol. 51, no. 1, pp. 7-13, 2018.

[4] J.-E. Kim, "A Study on the Correlation between English Word-final Stop and Vowel Duration Produced by Speakers of Korean," Phonetics and Speech Sciences, vol. 3, no. 1, pp. 15-22, 2011.

[5] M. Tadayon and G. J. Pottie, "Predicting Student Performance in an Educational Game Using a Hidden Markov Model," IEEE Transactions on Education, vol. 63, no. 4, pp. 299-304, 2020.

[6] R. Andrea, "Development of" Explores the Tenggarong City" Using Autonomous Response of Adaptive NPC". International Journal of Modern Education \& Computer Science, vol. 13 no. 1, 2021

[7] K. Park, B. W. Mott, W. Min, K. E. Boyer, E. N. Wiebe and J. C. Lester, "Generating Educational Game Levels with Multistep Deep Convolutional Generative Adversarial Networks," in 2019 IEEE Conference on Games (CoG), 2019.

[8] C. Tziortzioti, I. Mavrommati, G. Mylonas, A. Vitaletti and I. Chatzigiannakis, "Scenarios for Educational and Game Activities using Internet of Things Data," in 2018 IEEE Conference on Computational Intelligence and Games (CIG), 2018.

[9] A. Pitchai, A V Reddy, N. Savarimuthu,"Quantum Walk Algorithm to Compute Subgame Perfect Equilibrium in Finite Twoplayer Sequential Games", International Journal of Mathematical Sciences and Computing(IJMSC), Vol.2, No.3, pp.32-40, 2016

[10] M. Razakatiana, C. Kolski, R. Mandiau and T. Mahatody, "Human-agent Interaction based on Game Theory: Case of a road traffic supervision task," in 2020 13th International Conference on Human System Interaction (HSI), 2020.

[11] Y. F. Kurniawan, R. G. Isnanda, , \& A. Asroni, "The Development of 3D Survival Simulation Game for Identifying Safe Food and Water in Borneo Forest". Emerging Information Science and Technology, vol. 1 no. 1, pp 1-7, 2020

[12] R. Andrea, A. Nurhuda. " Developing Edu-Game "Ulun Smart-Kid" Learning Media of Banjar Language and Game Agent with Finite State Machine Model ", International Journal of Education and Management Engineering (IJEME), Vol.10, No.5, pp.1016,2020

[13] L. Zhao and K.-C. Chen, "The Game Theoretic Consensus in a Networked Multi-Agent System," in 2018 IEEE Global Communications Conference (GLOBECOM), 2018.

[14] M. Mendonca, K. Papageorgiou, D. E. d. Mello, E. I. Papageorgiou, J. A. Fabri, L. B. d. Souza and R. H. C. Palacios, "Digital game-based learning in a robotics course," in 2020 11th International Conference on Information, Intelligence, Systems and Applications (IISA, 2020.

[15] Emilisa and R. Darmakusuma, "Virtual Pet Game Application to Train and Manage How to Raise a Cat Well and Properly," in 2020 6th International Conference on Interactive Digital Media (ICIDM), 2020.

\section{Authors' Profiles}

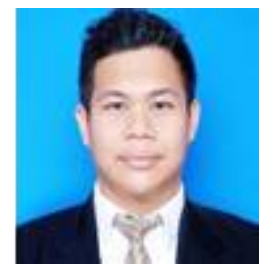

Reza Andrea, earned his Bachelor's degree from Computer Science, Mulawarman University in 2012. In 2013 he was involved in a game development project as a leader of Bibir Design Studio and he was awarded the best 2D game developers of Indonesia Game Show (IGS). In 2014, Reza Andrea earned his Master's Degree in Business Engineering from Department of Computer Engineering, STMIK Eresha, Jakarta. Now, he is a lecturer in Software Engineering Department in Polytechnic Agriculture of Samarinda and Expert Staff of Research Department in STMIK Widya Cipta Dharma. 


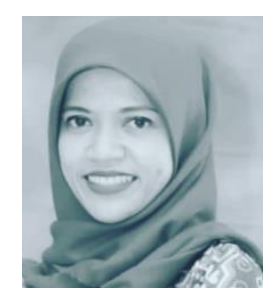

Sefty Wijayanti, S.Kom.M.Kom, was born in Samarinda on September 18, 1984. Continuing Bachelor Studies at Widya Cipta Dharma College of Information Managements (STMIK) Samarinda, Information System Study Program graduated (2010). Masters studies at Benarif Indonesia College of Information Technology (Eresha), Jakarta, Informatics Engineering graduated Study Program (2015). Thesis: Application of K-Means and Fuzzy C-Means Clustering Methods for Group Analysis of Student Graduates (Case Study at STMIK Widya Cipta Dharma). Lecturer at Widya Cipta Dharma College of Information Managements (STMIK) Widya Cipta Dharma Samarinda, East Kalimantan Province. Since 2005 until 2019, and has now passed away in carrying out his research process. This Paper is her last works.

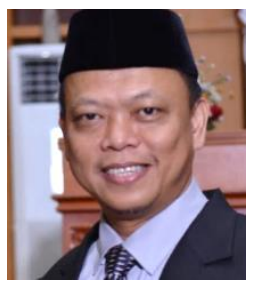

Dr. H. Nursobah, S.Kom.M.Kom, was born in Jakarta on Mei 20, 1972. Completed formal education in Elementary School (1985), Junior High School (1988), Senior High School (1991) in Jakarta. Continuing Bachelor Studies at Gunadarma University Depok, Computer Engineering Study Program graduated (1996). Masters studies at Benarif Indonesia College of Information Technology (Eresha), Jakarta, Informatics Engineering graduated Study Program (2001). Then Doctoral studies at 17 August 1945 University Surabaya, in Public Administration graduated (2015). Dissertation: The Influence of Organizational Justice, reward systems and training on job satisfaction and its implications for employee Organizational Citizenship Behavior. Lecturer at Widya Cipta Dharma College of Information Managements (STMIK) Samarinda, East Kalimantan Province. Since 1997 until now, and also served as Chariman of STMIK Widya Cipta Dharma.

How to cite this paper: Reza Andrea, Sefty Wijayanti, Nursobah, " Finite State Machine Model in Jungle Adventure Game an Introduction to Survival Skills", International Journal of Information Engineering and Electronic Business(IJIEEB), Vol.13, No.4, pp. 55-61, 2021. DOI: 10.5815/ijieeb.2021.04.05 